\title{
From Pentecost to Patmos: Acts to Revelation. Introduction and Survey
}

\section{Book Title:}

From Pentecost to Patmos:

Acts to Revelation.

Introduction and Survey

Book Cover:

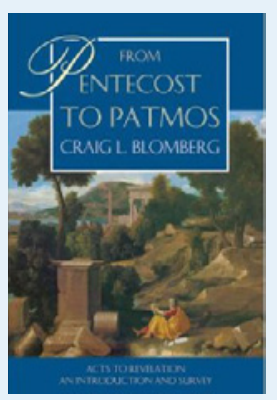

Author:

Craig L. Blomberg

ISBN:

978-1-84474-052-0

Publisher:

Nottingham: Inter-Varsity

Press, 2006, 592 p., £19 - 99*

(hardcover)

*Book price at time of review

Review Title:

From Pentecost to Patmos:

Acts to Revelation.

Introduction and Survey

Reviewer:

Christoph Stenschke ${ }^{1}$

\section{Affiliation:}

${ }^{1}$ Department of New

Testament; University of

South Africa; South Africa

Email:

stenschke@wiedenest.de

\section{Postal address:}

Biblisch-Theologischen

Akademie; Forum Wiedenest

Eichendorffstr. 2; D-51702

Bergneustadt; Germany

\section{How to cite this book}

review:

Stenschke, C., 2011, 'From

Pentecost to Patmos: Acts to

Revelation. Introduction and

Survey', Verbum et Ecclesia

32(1), Art. \#468, 2 pages.

doi:10.4102/ve.v32i1.468

C 2011. The Authors. Licensee: OpenJournals

Publishing. This work

is licensed under the

Creative Commons

Attribution License.
English-speaking students of theology (and their instructors!) are blessed with a wide choice of handbooks and introductions to the Bible for courses in Bible Survey Introduction to the New Testament. Several good volumes are available from an evangelical perspective. There have been excellent survey volumes on the whole New Testament (e.g. R.H. Gundry's A Survey of the New Testament, 4. edn.; Grand Rapids: Zondervan, 2007) as well as volumes on specific parts of the New Testament. This specific volume, which I received for reviewing purposes, belongs to the last category.

Those who (like me) use and value Blomberg's excellent textbook Jesus and the Gospels: An Introduction and Survey (Leicester: Apollos, 1997) will be pleased to see that Blomberg, distinguished professor of New Testament at Denver Seminary, has produced a volume of similar quality on the remaining parts of the New Testament.

In the brief "Introduction", Blomberg describes the origin and aims of the book. Whilst other volumes in the field concentrate on matters of introduction, theological significance or specialised forms of analysis that have been growing in popularity, Blomberg concentrates 'on detailed mastery of the meaning of texts of Scripture themselves' (p. 2). Therefore he only offers the most crucial items of introduction in enough detail to provide the necessary background for correctly interpreting New Testament books. The emphasis lies 'on surveying the actual structure and contents of each book, the main points in each section, the distinctive exegetical cruxes, and several key terms for contemporary application' (p. 3). Blomberg adopts what he calls a 'broadly based evangelical perspective' (p. 3). However, he has read widely, 'interacted with a broad cross-section of scholarship, and tried to offer representative sampling of approaches across a wide spectrum of theological commitments' (p. 3).

For each New Testament book Blomberg begins with introductory considerations. This is followed by abbreviated remarks in commentary form on the most central, interesting, relevant and/or controversial details of the book. Next, we have in Blomberg's own words:

passage-by-passage (at times even verse-by-verse) comments with footnotes to where specific concepts or quotations originate or to where fuller discussion of issues may be found. Finally, some brief remarks with respect to the contemporary application ... and a selective bibliography of works for further study.

Each chapter ends with review questions. In addition, italicised material, maps, charts and diagrams make the volume user friendly. Altogether, the book can best be described as a detailed survey of the New Testament, for all its worth and with the limitations of that emphasis.

The introduction contains brief reflections on the canon. The volume does not contain a historical or theological introduction to this part of the New Testament (Acts and the Epistles) or to the relationship of Jesus and the Gospels to Acts, the letters of the New Testament and the Book of Revelation. Neither does the volume offer a concluding chapter, summarising the purposes and theological emphases of these parts of the New Testament or their relationship to the first noncanonical writings of the ancient church.

"Part one" offers a detailed introduction to the Book of Acts ('The Gospel moves out', p. 9-82; 'because it appears immediately after the Gospels in canonical sequence and because it forms the narrative context into which many of the epistles may be inserted with greater understanding', p. 3).

"Part two" on Paul and his letters begins with a survey of Paul's life and ministry (p. 85-114). The letters appear in chronological order, in so far as their age can be reconstructed:

- Galatians: The Charter of Christian Liberty (p. 117-137)

- The Thessalonian Correspondence: A Balanced View of Christ's Return 
- 1 Thessalonians: Christ Is Coming Soon (p. 139-149)

- 2 Thessalonians: But Not That Soon! (p. 151-162)

- The Corinthian Correspondence: Countering Misguided Views about Christian Maturity:

- 1 Corinthians: Internal Immaturity and External Hellenizing Threats (p. 163-202)

- 2 Corinthians: Increasing Maturity but Infiltrating Judaizing Threats (p. 203-232)

- Romans: The Most Systematic Exposition of Paul's Gospel (p. 233-269)

- The Prison Epistles: General Introduction (p. 271-273)

- Philemon: A Christian Response to Slavery (p. 275-284)

- Colossians: Christ as Lord of the Cosmos and the Church (p. 285-301)

- Ephesians: Unity in Diversity as a Witness to the 'Powers' (p. 303-323)

- Philippians: Rejoice in All Circumstances (p. 325-341)

- The Pastoral Epistles: General Introduction (p. 343-349)

- Titus: A Manual on Church Order (p. 351-357)

- 1 Timothy: How to Pastor a Church and Turn It Away from Heresy (p. 359-373)

- 2 Timothy: Pass It On (p. 375-383).

"Part three" covers the other writings of the New Testament (p. 387-560) under the following headings:

- The Epistle of James: 'Faith without Works Is Dead' (p. 387-408)

- The Epistle to the Hebrews: The Superiority of Christ (p. 409-439)

- 1 Peter: Perseverance Despite Persecution (p. 441-460)

- The Epistle of Jude: 'Contend for the Faith' (p. 461-471)
- 2 Peter: 'Where Is the Promise of His Coming?' (p. 473483)

- The Epistles of John: The Tests of Life:

- 1 John: Countering the Secessionists (p. 485-498)

- 2 John: The Secessionists Attack from Outside (p. 499 501)

- 3 John: The Secessionists Take Over Inside? (p. 503507)

- The Book of Revelation: God's Plans for Cosmic History (p. 509-560).

The volume closes with indexes of subjects, authors and Scripture references (p. 561-577). It successfully achieves the goals that Blomberg set for himself and his readers (p. 6):

... to better understand first-century Christianity, the literature it produced that came to be treated as uniquely sacred, and through it a better appreciation of the Lord Jesus Christ, worshipped by this fledgling church, often in hostile circumstances and facing difficulties remarkably similar to those the church faces today throughout the world, despite the changes in cultural and technological forms in which those challenges may be cloaked.

Whilst he is well informed on current research, his aim is for students to read, understand and appreciate the texts themselves. This is welcomed in view of the increasing number of students in many training institutions who for a variety of reasons - do not come to their theological training with a sound knowledge and command of the New Testament. They need volumes such as this one before they can turn to volumes which focus more on critical scholarship of the New Testament rather than the actual content of the New Testament itself. 